\title{
How Much Am I Selling It for? Approaches and Methods of Patents Valuation in Technology Transfer Processes
}

\author{
Gustavo da Cruz ${ }^{1}$, Danilo Moreira Jabur ${ }^{1}$, Franklin Mendonça Goês Junior ${ }^{1}$ \\ ${ }^{1}$ Santa Cruz State University, Ilhéus, Bahia, Brazil \\ Correspondence: Gustavo da Cruz, Department of Management, Santa Cruz State University, Rodovia Ilhéus \\ Itabuna Km 16, Ilhéus, Bahia 45653-200, Brazil.
}

Received: February 3, 2017

Accepted: March 6, 2017

Online Published: March 8, 2017

doi:10.5539/ibr.v10n4p69

URL: https://doi.org/10.5539/ibr.v10n4p69

\begin{abstract}
Patent has assumed a protagonism in the transformation of knowledge and technology to allow some kind of economic exploration. However, researchers have some problems to define the correct value of their patent to sell it to industries or governments. The purpose of this paper is to explore the approaches and methods of patents valuation, especially in technology transfer process between universities-industries. It was made the review and examination cost-based, market-based and income-based approaches and their corresponding methods of patents valuation: Incurred-cost, costing, comparison-based and real options. Patent valuation will be presented to researchers, managers and other actors involved with innovation with the aim of creating at the universities their own valuation model focused on a better technology transfer process within industries, and consequently generate additional profits to the university third mission.
\end{abstract}

Keywords: patent, valuation, university, technology transfer, approaches, methods

\section{Introduction}

Universities have always been involved in technology transfer activities (Geuna \& Muscio, 2009), which are not something actually new because the university-industry collaboration begin back to the 1.800 s (Borrell \& Damian, 2010). However, only in early 1.980s, the number of universities that actively created ways for selling their ideas, technologies or products to industries or governments started to grow up (Ranga \& Garzik, 2015).

The result has been a reformulation of the researchers-inventors goals (Audretsch et al., 2014) which requires nowadays entrepreneurship and technology transfer competences able to generate, use, apply and explore academic results outside academic environment (Molas-Gallart \& Castro-Martínez, 2007). Nevertheless, it is an opportunity to go on with the opening of universities with the intention of starting an exchange outside the scientific environment and finding answers to social issues (Pausits, 2015).

Furthermore, patents or otherwise intellectual property protections to safeguard academic results represents a predisposition to allow some kind of exploration of these intellectual properties by industries or governments (Jensen \& Thursby, 1998; Siegel et al., 2003). In this context, patents assume a protagonism into the transformation of knowledge and technology to marketable products (Etzkowitz \& Leydesdorff, 2000; Grimaldi \& Grandi, 2005).

Thursby et al. (2001) and Frietsch et al. (2014), describes patent as a set of exclusive rights granted normally by a sovereign state according to national laws and international agreements to an inventor or assignee for a limited period of time to make, use and sell it, as well to exclude others from any kind of exploitation. In addition, a patent application must reveal all details of the invention, so that others can use it to further advance technology with new inventions (Jensen \& Thursby, 1998).

Definitely, selling products or technologies patents to non-academic institutions is not such a simple task for researchers-inventors, because there are many legal and practical limitations that do not concern daily activities of researchers (Wright et al., 2004; Ambos et al., 2008). However, regardless of the researcher-inventor fieldwork and experiences, the patent valuation is one of the most difficult steps on technology transfer process (Wu \& Tseng, 2006; Taheri \& Geenhuizen, 2016). 
In this context, the purpose of this paper is to analyze the approaches and methods of patents valuation, reference on the technology transfer process between universities-industries. The core argument is that the approaches and methods of patents valuation must be understood as a management tool that allows researchers to conduct a better commercialization process within industries. The methodology of this paper was designed to employ an inductive approach, in which it was made the review and examination of literature with intersections of patents valuation methods, technology transfer and other related themes.

This paper is organized in the following way: a discussion of the literature review in Section 2 about the technology transfer and commercialization. In section 3, it is placed the approaches and methods of patents valuation. The Section 4 is placed by the conclusions with the limitations of the research and directions for further researches.

\section{Technology Transfer and Commercialization}

With the aim of improving the innovation performance and build a competitive advantage for industries as well as universities, technology transfer plays an important role in the interface between basic science and product development (Ranga \& Garzik, 2015). Therefore, technology transfer can be defined by the movement of technology via some communication channels from one place to another, for example, from a university to an organization, or from a country to another (Rogers et al., 2001; Guan et al., 2006; Zhao \& Reism, 1992).

AUTM (2002) indicate points out the technology transfer as a process of transferring scientific findings from one organization to another. Gervais et al., (2016), on the other hand, point as a combination of activities that requires a multidimensional approach with a long-term process of interaction between organizations. Bukala (2008) also puts the technology transfer as an interaction instrument between two or more organizations during a knowledge or technical producing process to create a new product or service.

Nevertheless, technology transfer is not just a movement or delivery innovation. It is a dynamic, complicated and a multidisciplinary process whose success owes to factors coming from other sources (Jafari et al., 2014). Burhanuddin et al., (2009) argue that it is usually considered as a dissemination of information, harmonizing technology with needs and creative adaptation of items for new applications. In addition, technology transfer involves any kind of activities and processes through the incorporated products, processes, or knowledge which are passed from one user to another (Besant \& Rush, 1993).

The dynamic nature of technology transfer has contributed to the existence of many definitions and concepts (Chapple et al., 2005). However, based on literature studies (Etzkowitz \& Leydesdorff, 2000; Phan \& Siegel, 2006; Ranga \& Etzkowitz, 2013; Audretsch et al., 2014), it is evident that technology transfer has a wide conceptualization, because it refers to use, mobilization, application, exchange, development and management related to a product, service, technology and knowledge.

Bozeman (2000) argues that the definition of technology transfer sometimes can create a misunderstanding due to different references involved. However, the point is: it will be successful when the technology will be brought into the market, with a purpose for further use and commercialization (AUTM, 2002; Geuna \& Muscio, 2009). It is also important to note that analyzing and understanding technology transfer from universities into marketable ideas thus becomes one of the most important topics in academic research (Audretsch et al., 2014).

The technology transfer in a university-industry interaction perspective is able to produce innumerous benefits to society through promoting industries competitive advance and consequently improving national and regional economic growth (Phan \& Siegel, 2006; Perkmann et al., 2013). Although, these benefits in the universities are mainly focused on maximizing social return on public investment in research and effort to improve universities' self-sustenance (Gervais et al., 2016), creating revenue, which is typically reinvested in academic research (Chapple et al., 2005).

Furthermore, Zhao and Reism (1992) argue that the term "transfer" in addition with "technology", is usually involved in a "sale" of such technology. For this reason, the term "commercialization of technology" is found in several studies (Siegel et al., 2003; Chapple et al., 2005; Geisler \& Turchetti, 2015; Mattila \& Lehtimaki, 2016).

According to Geisler and Turchetti (2015), the main purpose of technology transfer is to generate a commercialization process in which the outcomes from researches play an important role in society. These outcomes are related to introducing a new idea, a technological solution, a product, a service, a process, a policy, an organizational form or a firm to the market (Markmann et al., 2005; Mattila \& Lehtimaki, 2016).Consequently, commercialization is related to all universities activities that are involved in achieving a new technology or any finding resulting from academic campus and the attempt to incorporate these results into the market (Geuna \& 
Muscio, 2009). Audretsch et al. (2014) emphasizes the key of technology transfer process in universities is to make the results marketable.

Perkmann et al. (2013) indicate that one of the universities commercialization goals is to generate intellectual property (invention disclosures and patenting) as well as its commercial exploitation by the creation of spinout companies or the licensing of inventions. It is important to recognize that the university based technology commercialization processes usually include a discovery, assessment for patentability and eventual attempts to transfer and license to the industry (Markmann et al., 2005)

However, this process depends on many factors to be successful, which includes, but are not limited to: inducements, engagement, network, policies, culture, resources and barriers (Siegel et al., 2003; Geisler \& Turchetti, 2015). Managing the technology transfer for commercial profit is a huge challenge, it can be painful and difficult to achieve (Wright et al., 2004; Ambos et al., 2008). Therefore, commercialization among universities, industries and other players cannot succeed without boundary-spanning activities in the organizations involved (Taheri \& Geenhuizen, 2016).

Patents or otherwise protection to safeguard university's intellectual property represents a disposition to allow some kind of exploration from industries or governments (Jensen \& Thursby, 1998; Siegel et al., 2003). Hence, license or otherwise commercialization mechanism represent an exploration of thus outcomes research with the objective to obtain financial rewards (Perkmann et al., 2013).

In this context, patents assume a protagonism into the transformation of knowledge and technology to marketable products (Etzkowitz \& Leydesdorff, 2000; Grimaldi \& Grandi, 2011). Geisler \& Turchetti (2015) mentioned that the number of patents jointly authored by the university and industry is a strong indication about the level of technology transfer between the organizations.

Despite evidence of some improvement in the commercialization process in recent years, there are still many gaps in universities that need to be mitigated or minimized to ensure that innovation will reach the market. One of these gaps is that researchers are having troubles to define the correct value of the patent that is going to be sold to the industries (Markmann et al., 2005) because the financial gains from this commercialization must cover or preferentially generate profits on the investments made by the universities (Mattila \& Lehtimaki, 2016)

The problem arises because information on technology cannot be provided like goods in general and, as a result, the role of a technology valuation as a complementary measure becomes very important (Baek et al., 2007; Yu \& Azevedo, 2008). Therefore, not all patents are equal and all patents have different economic impact, making careful selection and consideration of valuation procedures necessary (Wu \& Tseng, 2006). Next, the main approaches and methods of patent valuation will be presented to aiming researchers, managers and other actors involved with innovation. All these characters are going to design at universities their own valuation model focused on a better technology transfer process between the industries, and consequently generate a financial gain wanted.

\section{Approaches and Methods of Patents Valuation}

The term valuation refers to the task of determining the monetary value of an asset, object, technology, or entity over its future financial performance (Boer, 1999; Yu \& Azevedo, 2008). The task is quite similar to what investors normally hold on stock exchanges (Pitkethly, 1997) since valuation is determined on the basis of economic scenarios and return on investment analyzes (Amaral et al., 2014).

As patents valuation is the main scope of this paper, it must be understood as a task of establishing the monetary value of a new idea, of a new technology or of a new product to be commercialized for those interested in its economic exploitation in the future (Pitkethly, 1997; Geisler \& Turchetti, 2015; Mattila \& Lehtimaki, 2016).

Usually, patents from universities are valued for future licensing, royalties and acquisitions by industries. However, the main reason for valuing a patent is to maximize its value and, consequently, become an additional source of revenue for universities that reinvest in research (Tukoff-Guimarães et al., 2014).

Several authors (Smith \& Parr, 2000; Pitkethly, 1997; Hall, 2004; Wu \& Tseng, 2006) define three basic groups of patent valuation methodology: cost-based, market-based and income-based. Universities or inventor-researchers should choose one of three approaches, each one of them will embrace several methods that will determine how patent valuation will be carried out.

\subsection{Cost-based Approach}

This type of approach aims to determine the monetary value of the patent in relation to its development cost, in other words, how much was actually spent to create this new technology or product (Carte, 2005). This cost refers to the investments made from the development of the research to the patenting process, and the value of the total 
cost will serve as an initial basis to determine the sales value of this patent.

This approach can be used in two distinct marketing situations. The first refers to when the university or researcher-inventor seeks to determine all the amount spent on the development of this new technology or product and it has, as main objective, to recover the investment made. The second situation refers to the industries (potential buyers of the patent), since they can estimate the cost of inputs, equipment, taxes, among other things, to obtain this patent and to estimate the purchase value of it (Smith \& Parr , 2000).

For Santos and Santiago (2008), this approach has as its main advantage, to be a simplified process where the costs are determined directly with the information raised by the university or industry. The value of patents for new technologies is very high, since most of them have no similarity in the market, which makes valuation very difficult through market-based and income-based approaches (Martin \& Drews, 2006). However, this approach does not allow to determine the monetary benefits that a patent can bring in the future (Pitkethly, 1997), which is why Amaral et al. (2014) recommends that it should only be used only when there is insufficient information about future or market incomes.

Based on this approach, it is possible to user several patent valuation methods according to studies by Pitkethly (1997), Carvalho (2003), Wernke (2004), Hall (2004), Wu and Tseng (2006). However, this paper will only address the two main methods: Sunk cost and Costing.

\subsubsection{Sunk Cost}

For Carvalho (2003), this method is based on the concepts of cost accounting, in which the cost incurred is understood as the expenditure related to the goods or services used in the production of other goods or services. Smith and Parr (2000) adds that cost incurred is any expenditure that is directly or indirectly linked to the production effort of a good or service.

In this way, the cost method includes direct and indirect costs based on the patent produced, that is, all costs that are naturally identified by the cost object. These direct costs are those directly appropriated to the development, and indirect costs are not directly linked to the patent, being appropriate through apportionment parameters in which it comprises the division of several accounting items (Ferreira, 2007). The identification of direct costs during the conduct of research or the innovation process is more easily identified than the identification of indirect costs. Consequently, it is necessary to determine apportionment criteria to appropriate the indirect costs to the total cost of the patent (Amaral et al., 2014).

Wernke (2004) emphasizes that this method aims to clearly define all the financial operations used for the development of a patent, since the costs can be grouped and organized according to their origins in order to produce information that will serve as a basis for defining the value of the patent to be marketed.

\subsubsection{Costing Approach}

According to Souza (2008) the costing method should be understood as a set of technical and accounting elements that can be managed harmonically in order to create a desired financial map. For Leone (2000), this method provides an opportunity for current financial results to be analyzed and also to identify tax liabilities. Crepaldi (2004) understands that the costing method assists the process to determine the value of the patent, since it provides information in which it is possible to create correlations between cost, volume of production and profit.

According to Martin and Drews (2006), the costing method becomes extremely interesting for purposes of patent valuation, considering that fixed costs are understood as the financial efforts of the university or of the researcher to have the operational conditions to carry out the research, as well as identify the costs by grouping direct and indirect costs. It should be noted that these fixed and variable costs are easy to identify since the organization and financial control of them are the responsibility of the university or the responsibility of the researcher.

According to Smith and Parr (2000), there are different ways of classifying the costing method. The first is related to its production activity (cost per order of production or process. The second is related to the form of appropriation (standard, absorption or direct variable). Bruni and Famá (2004) adds that the costing method must be used with extreme care, since it has management purposes and often its theoretical concepts are not applicable to the commercialization of patents.

\subsection{Market-based Approach}

This approach is the most used by researchers-inventors, because it seeks to find the real and present value of a similar patent in the market. Martin and Drews (2006) points out that in this real value, tangible and intangible assets are included and the difference between the market value and the book value is close to the sales value of this patent. In economic terms, Wu and Tseng (2006) emphasize that in this approach, the patent has two values since 
the cost of developing the patent becomes the minimum value of commercialization while the demand (quantity of possible buyers) determines the sale value.

For Flignor and Orozco (2006) the market-focused approach usually occurs in two steps. The first is the screening, where the processes of similar commercial transactions of this patent are located. The second is the adjustment stage, when the parameters for the analysis of this valuation are defined by techniques, interpretations and estimates of data in the market. However, to take a market-based approach, it is necessary to have reliable accounting data for an impartial analysis as well as several similar patent statistics (Baek et al., 2007).

This approach has the advantage of defining the value of the patent to be sold closer to those used in the market. On the other hand, a very large amount of business information is required in which the patent is inserted for valuation to succeed (Martin \& Drews, 2006; Flignor \& Orozco, 2006). Among them, the following stand out: consolidated and reliable bibliography; support from renowned international institutions; as well as a database of the research institution (Tukoff-Guimarães et al, 2014). However, since some information on commercial transactions is kept confidential, this approach may be impaired because the comparison may become impracticable.

\subsubsection{Comparison-based Method}

The comparative-based method is the most intuitive of all valuation methods by comparing the same items in different places. According to Smith and Parr (2000), it is the method used by the researchers-inventors, because when estimating re-creation costs based on previous research and adding an estimated future value of this patent, it is possible to easily and quickly obtain a value that is compatible with the market.

Meanwhile, since most patents have very specific characteristics and their marketing transactions are restricted among the parts involved, this method may become impractical in the brand valuation process. Ross (1997) points out two basic premises for applying this method successfully: own an environment with a great deal of information about the process of buying and selling similar patents, as well as the identification and access of these commercial contracts. Baek et al. (2007) add that this method should only be used when there is similar information on development costs and commercial transactions available in the market for the comparison to be carried out effectively.

\subsection{Income-based Approach}

HIPO (2011) conceptualizes the approach with focus on the income as a slope that qualifies the future potential of possible generations of values from the commercial exploitation of the patent. Flignor and Orozco (2006) point out that this approach uses the basic premise of definitions that the value of the patent to be marketed is determined by the ability to generate future income for its owners.

Pitkethly (1997) points out that this approach is more complex than cost or market ones, since it requires a greater volume of data to generate future cash flows. Some factors are essential in this approach to determine patent valuation, such as an estimation of sales revenues, shelf life and market acceptance risk. HIPO (2011) complements that it is essential to know the forecast of discount rates, market, competition and financial returns from the exploitation of this new asset or technology.

Based on this approach, the authors Pitkethly (1997), Hall (2004), Flignor and Orozco (2006), Martin and Drews (2006) and Baek et al. (2007) present several methods. But in this paper, the method will be approached by real options because it is the most used in the valuation of patents.

\subsubsection{Real Options Method}

The real options method comes from financial options, widely practiced in the real estate securities market. For Cerbasi (2014), this method is a contractual agreement made between the parts, in which one of them pays a price to acquire a right to decide, within a given period, whether or not to negotiate the patent, for a value decided in advance.

The real options method is interesting according to Carter (2005) since it provides opportunities to increase profits or reduce losses according to the intention of the universities. This fluctuation in value can be defined naturally on the basis of costs or as an investment opportunity because the present value of the cost may change at a later date according to the projection of the initial investments (Pitkethly, 1997).

Futures and options markets are a reference for price formation derived from commodities and financial assets. According to Oliveira (2014), this method was designed to protect variation of commodity prices for producers and traders exposed to risks during periods of scarcity and overproduction of the traded product, reducing the risk of price fluctuations.

The valuation method for real options must be understood with one of the methods that allows greater flexibility than the others, since it can be more aligned with the economic view of the market. This flexibility allows the 
parties involved to decide on the economic scenario, and whether they wish to invest in a new project or expansion or give up the investment. Cerbasi (2014) adds that the real options method is a natural consequence of the circumstances created by the competitive world of business and that provide characteristics of irreversibility, uncertainty and possibility of postponement.

\section{Concluding Remarks}

Given the scarcity of research in the area of patent valuation and its interface with technology transfer, this article presented the main approaches and valuation methods, as well as a vast literature review related to those topics.

We are aware that setting the selling price of a patent is extremely complex, as well as not part of the scientific activities of most researchers. However, technology transfer between university-industry will occur with increasing frequency and will require researchers-inventors to be able to value their patents and to realize the marketing process in the best possible way.

It is important to emphasize that although there are three patent valuation approaches that have their respective methods, they must be analyzed by the inventors or managers of the Technology Transfer Office to define which should be used, since each approach and method has very singular specifications that may or may not be in line with the patent being marketed.

In this context, the need to develop research in the area of patent valuation and commercialization, especially in developing countries, in which the process of technology transfer in the universities is still very immature. The approaches and valuation methods presented make it possible to carry out new analyzes and interpretations so that the definition of the value of a patent occurs in a fairer way.

\section{References}

Amaral, H. F., Iquiapaza, R. A., Correia, L. F., Amaral, G. H. O., \& Vieira, M. V. (2014). Avaliação de Ativos Intangíveis: Modelos alternativos para determinação do valor de patentes. Revista Gestão. Finanças $e$ Contabilidade, Salvador, 4(1), 123-143.

Ambos, T. C., Mäkelä, K., Birkinshaw, J., \& d'Este, P. (2008). When does university research get commercialized? Creating ambidexterity in research institutions. Journal of Management Studies, 45(8), 1424-1447. https://doi.org/10.1111/j.1467-6486.2008.00804.x

Audretsch, D. B., Lehmann, E. E., \& Wright, M. (2014). Technology transfer in a global economy. Journal Technology Transfer, 39, 301-312. https://doi.org/10.1007/s10961-012-9283-6

AUTM. (2002). The AUTM Licensing Survey: Fiscal Year 2000. Association of University Technology Managers, Norwalk, CT.

Baek, D. H., Sul, W., Hong, K. P., \& Kim, H. (2007). A technology valuation model to support technology transfer negotiations. $R \& D$ Management, 37(2), 123-138. https://doi.org/10.1111/j.1467-9310.2007.00462.x

Bessant, J., \& Rush, H. (1993). Government support of manufacturing innovation: two country level case study. IEEE Transactions of Engineering Management, 40(1), 79-91. https://doi.org/10.1109/17.206655

Boer, F. P. (1999). The valuation of technology: Business and financial issues in R\&D, Wiley, New York.

Borrell-Damian, L. (2010). Collaborative Doctoral education: University-industry partnerships for enhancing knowledge exchange. DOC-CAREERS Project. Brussels: European University Association.

Bozeman, B. (2000). Technology transfer and public policy: a review of research and Theory. Research Policy, 29, 627-655. https://doi.org/10.1016/S0048-7333(99)00093-1

Bruni, A. L., \& Famá, R. (2014). Gestão de custos e formação de preços: com aplicações na HP 12C e Excel. 3. São Paulo, Atlas.

Bukala, A. (2008). What innovation and technology transfer really mean? Journal of Automation, Mobile Robotics \& Intelligent Systems, 2(2), 70-72.

Burhanuddin, M. A., Arif, F., Azizah, V., \& Prabuwono, A. S. (2009). Barriers and challenges for technology transfer in Malaysian small and medium industries. In Information Management and Engineering, 2009. ICIME'09. International Conference on, 258-261. https://doi.org/10.1109/ICIME.2009.39

Carte, N. (2005). The maximum achievable profit method of patent valuation. International Journal of Innovation and Technology Management, 02(02), 135-151. https://doi.org/10.1142/S0219877005000435

Carvalho, F. T. (2003). Gestão de custos de serviços: a importância de sua análise na tomada de decisão. Monografia, Faculdade de Diadema, Diadema, 2003. 
Cerbasi, G. P. (2014). O que é e como funciona a técnica de Opções Reais para Avaliar Projetos de Investimento. Cavalcante Consultoria, São Paulo. Retrieved 04.11.2016, from http://www.cavalcanteassociados.com.br/vtd/uptodate104.pdf

Chapple, W., Lockett, A., Siegel, D., \& Wright, M. (2005). Assessing the relative performance of U.K. University technology transfer offices: Parametric and non-parametric evidence. Research Policy, 34(3), 369-384. https://doi.org/10.1016/j.respol.2005.01.007

Crepaldi, A. S. (2004). Curso Básico de Contabilidade de Custos. São Paulo, Editora Atlas.

Etzkowitz, H., \& Leydesdorff, L. (2000). The dynamics of innovation: from National Systems and "Mode 2" to a Triple Helix of university-industry-government relations. Research policy, 29(2), 109-123. https://doi.org/10.1016/S0048-7333(99)00055-4

Ferreira, J. A. (2007). Custos industriais: uma ênfase gerencial. São Paulo, STS.

Flignor, P., \& Orozco, D. (2006). Intagible Asset \& Intellectual Property Valuation: A Multidisciplinary Perspective. Retrieved 12.09.2016, from www.wipo,int7sme/en/documents/ip-valuation.htm

Frietsch, R., Neuhäusler, P., Jung, T., \& Van Looy, B. (2014). Patent indicators for macroeconomic growth-the value of patents estimated by export volume.Technovation, 34(9), 546-558. https://doi.org/10.1016/j.technovation.2014.05.007

Geisler, E., \& Turchetti, G. (2015). Commercialization of Technological Innovations: The Effects of Internal Entrepreneurs and Managerial and Cultural Factors on Public-Private Inter-Organizational Cooperation. International Journal of Innovation and Technology Management, 12(02), 1550009. https://doi.org/10.1142/S0219877015500091

Gervais, M. J., Marion, C., Dagenais, C., Chiocchio, F., \& Houlfort, N. (2016). Dealing with the complexity of evaluating knowledge transfer and innovation performance: Evidence from Chinese firms. Technological Forecasting \& Social Change, 73, 666-678.

Geuna, A., \& Muscio, A. (2009). The Governance of University Knowledge Transfer: A Critical Review of the Literature. Minerva, March, 93-114. https://doi.org/10.1007/s11024-009-9118-2

Grimaldi, R., \& Grandi, A. (2005). Business incubators and new venture creation: an assessment of incubating models. Technovation, 25, 111-121. https://doi.org/10.1016/S0166-4972(03)00076-2

Guan, J. C., Mok, C. K., Yam, R. C. M., Chin, K. S. M., \& Pun, K. F. (2006). Technology transfer and innovation performance: Evidence from Chinese firms. Technological Forecasting \& Social Change, 73, 666-678. https://doi.org/10.1016/j.techfore.2005.05.009

Hall, B. H. (2004). Exploring the patent explosion. The Journal of Technology Transfer, 30(1-2), 35-48. https://doi.org/10.1007/s10961-004-4356-9

HIPO - Hungarian Intellectual Property Office. (2011). IP Valuation at Research Institutes: an essential tool for technology transfer. Budapest: HIPO.

Jafari, M., Akhavan, P., \& Rafieli, A. (2014). Technology transfer effectiveness in knowledge-based centers: Providing a model based on knowledge management. International Journal of Scientific Knowledge, 4(7), 24-38.

Jensen, R., \& Thursby, M. (1998). Proofs and prototypes for sale: the tale of university licensing. National Bureau of Economic Research, 6698. https://doi.org/10.3386/w6698

Markman, G. D., Gianiodis, P. T., Phan, P. H., \& Balkin, D. B. (2005). Innovation speed: Transferring university technology to market. Research Policy, 34, 1058-1075. https://doi.org/10.1016/j.respol.2005.05.007

Martin, D., \& Drews, D. C. (2006). Intellectual property valuation techniques. The Licensing Journal.

Mattila, M., \& Lehtimaki, H. (2016). Networks in Technology Commercialization. South Asian Journal of Business and Management Cases, 5(1), 43-54. https://doi.org/10.1177/2277977916634235

Molas-Gallart, J., \& Castro-Martínez, E. (2007). Ambiguity and conflict in the development of 'Third Mission'indicators. Research Evaluation, 16(4), 321-330. https://doi.org/10.3152/095820207X263592

Oliveira, E. (2014). Ganhe dinheiro na Bolsa de Valores com Opções. Edd Oliveira Publicações Série Viva Melhor sem Dívidas. Campo Grande, MS.

Pausits, A. (2015). The Knowledge Society and Diversification of Higher Education: From the Social: Contract 
to the Mission of Universities. In: Curaj, A. et al. (Org.) The European Higher Education Area: Between Critical Reflections and Future Policies. Springer. https://doi.org/10.1007/978-3-319-20877-0_18

Perkmann, M., Tartari, V., McKelvey, M., Autio, E., Broström, A., D’Este, P., \& Krabel, S. (2013). Academic engagement and commercialisation: A review of the literature on university-industry relations. Research policy, 42(2), 423-442. https://doi.org/10.1016/j.respol.2012.09.007

Phan, P. H., \& Siegel, D. S. (2006). The Effectiveness of University Technology Transfer. Foundations and Trends in Entrepreneurship, 2(2), 77-144. https://doi.org/10.1561/0300000006

Pitkethly, R. (1997). The valuation of patents: a review of patent valuation methods with consideration of option based methods and the potential for further research. Research Papers in Management Studies-University of Cambridge Judge Institute of Management Studies.

Ranga, M., \& Etzkowitz, H. (2013). Triple Helix systems: an analytical framework for innovation policy and practice in the Knowledge Society. Industry \& Higher Education, 27(3), 237-262. https://doi.org/10.5367/ihe.2013.0165

Ranga, M., \& Garzik, L. (2015). From Mozart to Schumpeter: A Triple Helix Systems approach to advancing regional innovation in the Salzburg region of Austria. In: Austrian Council for Research and Technology Development (Ed., 2015): Designing the future: economic, societal and political dimensions of innovation. Echomedia Buchverlag, Vienna.

Rogers, E. M., Takegami, S., \& Yin, J. (2001). Lessons learned about technology transfer. Technovation, 21, 253-261. https://doi.org/10.1016/S0166-4972(00)00039-0

Ross.A, da KPMG Peat Marwick LLP, San Francisco in "Finding the True Worth of Trade Marks and Brands", p. 1, publicado no Trade Mark Yearbook 1997

Santos, D. T. E., \& Santiago, L. P. (2008). Métodos de valoração de tecnologias. Belo Horizonte: Laboratório de Apoio à Decisão e Confiabilidade, Departamento de Engenharia de Produção, UFMG.

Siegel, D. S., Waldman, D. A., Atwater, L. E., \& Link, A. N. (2003). Commercial knowledge transfers from universities to firms: improving the effectiveness of university-industry collaboration. The Journal of High Technology Management Research, 14(1), 111-133. https://doi.org/10.1016/S1047-8310(03)00007-5

Smith, G. V., \& Parr, R. L. (2000). Valuation of intellectual property and intangible assets (Vol. 13). Wiley.

Souza, L. E. (2008). Fundamentos da contabilidade gerencial: um instrumento para agregar valor. Curitiba, Juruá.

Taheri, M., \& Geenhuizen, M. (2016). Teams' boundary-spanning capacity at university: Performance of technology projects in commercialization. Technological Forecasting \& Social Change, in press. https://doi.org/10.1016/j.techfore.2016.06.003

Thursby, J. G., Jensen, R., \& Thursby, M. C. (2001). Objectives, characteristics and outcomes of university licensing: A survey of major US universities. The journal of Technology transfer, 26(1-2), 59-72. https://doi.org/10.1023/A:1007884111883

Tukoff-Guimarães, Y. B., Kniess, C. T., Maccari, E. A., \& Quonian, L. (2014). Valoração de patentes: o caso do núcleo de inovação tecnológica de uma instituição de pesquisa brasileira. Exacta, 12(2), 161-172.

Wernke, R. (2004). Gestão de custos: Uma abordagem prática. São Paulo, Atlas.

Wright, M., Birley, S., \& Mosey, S. (2004). Entrepreneurship and University Technology Transfer. Journal of Technology Transfer, 29, 235-246. https://doi.org/10.1023/B:JOTT.0000034121.02507.f3

Wu, M. C., \& Tseng, C. Y. (2006). Valuation of patent-a real options perspective. Applied Economics Letters, 13(5), 313-318. https://doi.org/10.1080/13504850500393477

Yu, A., \& Azevedo, P. (2008). Valoração de tecnologias: questões chave para aplicação. Revista Conecta, 64-66.

Zhao, L., \& Reisman, A. (1992). Toward Meta Research on Technology Transfer. IEEE Transactions on Engineering Management, 39(1), 13-21. https://doi.org/10.1109/17.119659

\section{Copyrights}

Copyright for this article is retained by the author(s), with first publication rights granted to the journal.

This is an open-access article distributed under the terms and conditions of the Creative Commons Attribution license (http://creativecommons.org/licenses/by/4.0/). 